\title{
The Subjective Dimension and Contemporary Significance of Marx's
}

\author{
Wealth View
}

\author{
Zhao Helan \\ School of Marxism, Tianjin University Of Commerce,Tianjin, 300134, China \\ helan@163.com
}

Key words: Marx; wealth view; the main body form; the object form; social wealth; personal wealth

\begin{abstract}
Wealth is the material basis of human life and the realization of the human body life itself. At present, the human wealth develops by leaps and bounds. People still understand wealth only from the objective dimension. And people simply equate the wealth creation to abstract numerical growth that represent the material growth or wealth accumulation of items, for those people, they just in the name of illusory social wealth accumulation to suppress the personal desire of people from their own personal nature. And even the social people are made into the accessory of consumerism and one-sided collectivism. In our country contemporary wealth theory, there are also people simply put Marx's wealth view into critical productivity chapters to understand economics, and they make it dogmatic in the market economy system. Therefore, it would cause the one-sided danger of misusing. Although the western Marxism did not put forward the realistic path to achieve main-body wealth dimensions, the excellent ingredients in their theory should be taken as reference.
\end{abstract}

\section{Introduction}

On the relationship between subject and object dimensions, Marx foothold on the sensible and objective activity, and this activity is a practice that truly combine the subject and the object, namely the object is controlled by the subject. On relationship dimension between the society and personal, Marx expressed objective idea about his understanding of necessity of social historical development. Besides, he also studied the all-round development trend of "realistic individual" behind the law. The basic path of Marx's philosophy lies in the deep concerning to the individuality in the relationship between the society and personality and stressing the subject status of human subjectivity. And the core of the common problem is the main body dimension of human society development.

How to make the subject in sensible activities objective, and how is the result of the object that have gone through objectification? Whether the All the free and all-round development of the individual can be obtained from the general abstract society? This needs us to further explore the important wealth theory of Marxist philosophy system. The discussion of Marxist wealth theory needs to take the theory path in the main dimensions demonstrated in Marxist philosophy as the base, and elucidate it in double philosophy dimensions. And we should not be limited to the theory thought of Marx's philosophy and social personality view, nor should we simply take the wealth theory as evidence of Marx's historical materialism.

Overall, researches of the wealth theory and other economic problems at home and abroad provided us certain theoretical direction of reality traction for us to study the wealth problem. However, scholars haven't made clear the subjective dimension of the wealth in double dimension 
indexes, namely between subject and object, and society and individuals, thus, they ignored the true nature of wealth.

\section{On Contemporary Significance of Marx's Main Wealth View}

Since the 20th century, profound changes have been taking place in the world. Peace and development become the world recognized theme. For maintaining peace is to create a stable and orderly development environment, so in the end, development is the main point of the theme. Then, what kind of development is the one that human beings should pursuit, and whether the revolution we are working at toward the world is consistent with human appeal? It is obvious to all. The modern industrial society has brought the global economy development and the world material goods a super abundance. However, the global sexual problems, equality problems and ecological problems and so on make people doubting its development model and way of life and even deny the industrial development. Under this background, the growing subjectivity problem under the situation that the objective wealth growing leaps and bounds are gradually was focused on. The phased achievements in modern development and people's growing requirements for improving wealth structure make it necessary for us to further excavate the true meaning of Marx's historical materialism theory and grasp the correct direction of the development of the good fortune.

The Echo and Supplement of Western Marxism toward the Main Wealth Dimension. Western Marxism focuses on the subjectivity quality of wealth, which enlightens Chinese socialist modernization that: the establishment of the socialist market economic system has a positive role in the development of person's subjectivity. But at the same time, with the development of science, technology and economy, some negative factors would appear from different levels, thus there is materialization and alienation. That is to say, we should not only pay attention to material life, the development of production, but also should pay more attention to the realization of rich cultural wealth, humanistic moral and human nature. In this way, we could rescue people from the plight they are in due to the lack of attention to the future, and guide people to pursue life with better cultural quality, and them to achieve comprehensive development in the physical, cultural, moral, aesthetic and so on aspects. And finally we could strengthen people's subjectivity to promote the construction of socialist modernization. But they just want to transform society through mind revolution and ideological remolding. Yet they still stay in the rut of consciousness philosophy, and don't truly realize the reconstruction of the wealth of subjectivity. This kind of talk is based on the situation that breaks away from the social reality and the social history, so it is pointless.

Practical Significance of Marx's Main Wealth Dimensions. (1) Biased error in understanding wealth in the Chinese modernization process. Since China's reform and opening up, China's economy is booming. And China basically realized the well-off society development goal. Merely from the perspective of the growth of GDP, social wealth cake has done more than one hundred times in the early reform and opening up stage, thus China's modern industrial production development is said have created a remarkable wealth growth miracle. However, in the meantime that the country continue to do big wealth cake at the same time, in spite of its historical inevitability and rationality in the method of allocating resources and wealth distribution policy that "takes economic construction as the center" and "the rich first push on those being rich later", if these policies break away from the ultimate goal that the essence is taking people as the main body to achieve its aim must also bring its historical limitations. Because the long-term focus on GDP growth as the core of social wealth growth making the connotation of the productivity development direct regulated as the partial growth of material wealth, which would inevitably make the wealth trajectory deviation occurs, and the income distribution pattern, life quality and ecological environment balance will also be in anomie in the process of economic and social transformation. 
Such social wealth growth not only can't satisfy people desire of living a better life, and make the disparity between the rich and the poor getting greater, and arouse the pessimism among people about living in this environment, but also will constitute the root of all kinds of current social problems and social contradictions. (2) Scientific Understanding of "People-oriented" Wealth Concept in Scientific Development. The concept of scientific development aims to change the part, in the material wealth growth and growth mode, which is not suitable for the economic and social development. Transformation of the mode of economic growth is to get the economic development center back to development track where there is low consumption of environment resource, quality and performance being equally stressed, and environmental protection and innovation investment being encouraged, investment, consumption and export are being paid equal attention. And the above situation is economic, political and cultural coordinated in society. In 2012, the fifth session of the 11th National People's Congress for the first time cut $0.5 \%$ growth rate of China's expected gross domestic product (GDP), which creates atmosphere and conditions to change the wealth growth mode. Take the initiative to adjust GDP growth is the implementation of the scientific development concept, the consensus also further liberated the wealth view of the country and people. Cut growth, of course, is not to slow down the development. Cutting growth means no longer take GDP as the only measure of economic growth. And cutting growth means bringing the synchronous development of sustainable environmental resources, the improving of people's living quality, the narrowing of the gap between rich and the poor, social security, social public service, education and cultural undertakings, and the political and spiritual civilization on the agenda. On the one hand, we should promote the high-speed development of social productivity "to create the common possession social members on nature and society connection itself”, thus to create and establish sufficient material conditions for the comprehensive and free development of human beings. In this way, we lay an objective wealth base for society. On the other hand, to pay attention to the comprehensive, coordinated and sustainable development in our country is the grasp of the concrete contents of wealth. And emphasis on "people-oriented" development of wealth is the embodiment of the main wealth dimensions. Therefore, the above double comprehension and guiding are the practice of the Marxist concept of wealth. Besides, it is a resolution process of the conflicts among people, between people and society, between man and nature. "People-oriented" development is the historical trend of wealth and production mode as well as the realistic requirement of socialism being superior to capitalism. (3) Improving people's livelihood and building a shared society are the inevitable choices to realize "personal fortune". First of all, the real socialism should pay close attention to the livelihood of the people, thus to create all a shared society for the people. "End the situation that sacrifices the interests of some people to meet the needs of others", and make "all the people enjoy the welfare created by them", and "make all the social members obtain comprehensive development". The above are the agreed development direction of people about the social wealth. Second, common prosperity is the essence of unifying social wealth and personal wealth, the present development of China's wealth should be more towards the realization of personal wealth. Bear in mind Marx philosophy "avoiding taking 'society' as an abstract thing opposing to individual”, and take the development of the productive forces, creating social wealth and realizing the fairness and justice, in this way to bring the enjoying of wealth on the shoulders of all socialist builders. The above two aspects are complementary to each other in the socialist construction process. Third, “improving people's livelihood” and building a "sharing society" are two aspects of altering the wealth development direction in China, and the two complement to each other. When people's urgent desire transforms from "to be strong” to "to be rich", our aim of changing development direction would also is accomplished. In the new period, fair competition of the first distribution in our country and stable development in the secondary 
distribution, "tax policy that adjust the high-income people, promote the medium-income and help the low-income”, strengthening the inclusive innovation and regulation of the capital market, rational development and protection of the ecological environment, the promoting of employment, housing and food security, strengthening the medical and health reform, promoting education and cultural development and other areas of the various people's livelihood will become the main battlefields of building a shared society and letting all the potential and enthusiasm of community members to be fully erupted while creating wealth.

\section{Conclusion}

Marxist theory undoubtedly has a guiding position in the process of establishing the socialist harmonious society in our country. The 12th five-year plan is an important decision to successfully transform our country's economy. From the main dimension to understand the wealth concept means to interpret the essential connotation of wealth as "all personal and developed productivity" and as "all people's free and all-round development". Then the wealth connotation would be helpful for us to realize the scientific and reasonable wealth view that has human nature, and for us to carry the scientific concept of development into the practice of creating wealth. In this article, we explore the true meaning of wealth and the correct road for human being to pursuit shared wealth path. By this way, we arouse the all-round new attention of society to the human wealth, and make the society to redefine the nature and purpose of wealth. From the interpretation of Marxist philosophy, we want to inspire people to form a new concept toward treating wealth. In china, the research of this issue has particularly important value in the social developing process that take the market as the orientation, especially in beginning phase of the 12th five-year plan. Besides, this research is crucial to the implementation of this plan.

\section{References}

[1] Adam Smith. The nature and causes of the wealth of nations [M]. Beijing: the Commercial Press, 1974:1 48

[2] Ricardo of political economy and taxation principle [M]. Beijing: the Commercial Press, 1962:232-245.

[3] Hegel. Historical research fragment, citing Song Zuliang. Young Hegel's Philosophy [M]. Hunan: Hunan Education Press, 1989:170.

[4] Hagel. Phenomenology of spirit: Volume [M]. Beijing: the Commercial Press, 1979:146. 